\title{
RATIONALE FOR REMOVING NEVUS SEBACEUS OF JADASSOHN IN YOUNG PATIENTS
}

\author{
Gaydina $\mathrm{TA}^{1,2}$, Dvornikov AS ${ }^{1}$, Skripkina PA${ }^{1}$, Arutyunyan GB ${ }^{1}$ \\ ${ }^{1}$ Department of Dermatology and Venereology, Faculty of General Medicine, Pirogov Russian National Research Medical University, Moscow \\ ${ }^{2}$ REDNOR OOO, Moscow
}

\begin{abstract}
Nevus sebaceous of Jadassohn (NSJ) is a benign skin lesion, a hamartoma typically localized to the face or scalp and equally common in men and women. Pluripotent epithelial cells that give rise to NSJ provide a favorable environment for benign and malignant tumors to form in the nevus. Because of the possibility of malignant transformation, NSJ should be removed after puberty. If surgery is impossible, long-term observation is indicated. In this work we present two cases of successful NSJ treatment with the $\mathrm{CO}_{2}$ laser in young patients.
\end{abstract}

Keywords: nevus sebaceus of Jadassohn, benign skin lesion, malignant nevus transformation, $\mathrm{CO}_{2}$ laser treatment

$\triangle$ Correspondence should be addressed: Tatiana A. Gaydina

Ostrovityanova 1, 117997; doc429@yandex.ru

Received: 05.05.2018 Accepted: 12.07 .2018

DOI: $10.24075 /$ brsmu.2018.033

\section{АКТУАЛЬНОСТЬ УДАЛЕНИЯ НЕВУСА ЯДАССОНА У ЛИЦ МОЛОДОГО ВОЗРАСТА}

\author{
Т. А. Гайдина ${ }^{1,2 凶}$, А. С. Дворников ${ }^{1}$, П. А. Скрипкина' 1 Г. Б. Арутюнян ${ }^{1}$ \\ ${ }^{1}$ Кафедра дерматовенерологии, лечебный факультет, Российский национальный исследовательский медицинский университет имени Н. И. Пирогова, Москва \\ 2 ООО Компания РЕДНОР, Москва
}

Одним из доброкачественных образований кожи является себорейный невус Ядассона (NSJ) - гамартома, локализующаяся преимущественно на коже лица или волосистой части головы и одинаково часто встречающаяся у мужчин и женщин. Плюрипотентные первичные эпителиальные клетки, входящие в структуру NSJ, являются благоприятной средой для развития на его фоне как доброкачественных, так и злокачественных опухолей. Для исключения неопластической трансформации целесообразно удалять NSJ сразу после полового созревания. При невозможности хирургического вмешательства пациентам требуется постоянное динамическое наблюдение. В данной работе представлено два случая успешного удаления $\mathrm{CO}_{2}$-лазером NSJ у пациентов молодого возраста.

Ключевые слова: невус себорейный Ядассона, доброкачественные образования кожи, злокачественная транссормация невуса, удаление $\mathrm{CO}_{2}$-лазером

$\triangle$ Для корреспонденции: Гайдина Татьяна Анатольевна

ул. Островитянова, д. 1, г. Москва, 117997; doc429@yandex.ru

Статья получена: 05.05.2018 Статья принята к печати: 12.07.2018

DOI: $10.24075 /$ vrgmu.2018.033

Hamartomatous sebaceous glands were first described by the German dermatologist Joseph Jadassohn in 1895 [1]. Nevus sebaceus of Jadassohn (NSJ, sebaceous nevus) is a congenital organoid nevus typically localized to the face or scalp and equally common in men and women (Fig. 1). The nevus arises from pluripotent stem cells differentiating into mature sebaceous and apocrine structures and is a result of the overgrowth or malformation of sebaceous glands [2]. Clinically, NSJ appears as an asymptomatic solitary plaque slightly raised above the skin surface; the plaque is up to $10 \mathrm{~cm}$ in size, round or linear in shape and consists of small hemispheric smooth-surfaced or papillomatous pink, yellow or brown papules. NSJ manifestations evolve with age as sebaceous and sweat glands undergo their differentiation [3]. In infancy the plaque is hairless, not very conspicuous and has a smooth or papillary surface. In puberty NSJ becomes more prominent, develops closely set papules ranging in color from yellowish to dark brown. In older patients NSJ appears as epidermal hyperplasia and malformed sebaceous lobules, involving many different epithelial structures, such as dilated apocrine glands or abortive hair follicles [4]. Teenagers often have conglomerates of undifferentiated cells resembling basal cell carcinoma [2].

In this work we present two clinical cases of nevus sebaceus treated with the $\mathrm{CO}_{2}$ laser.

\section{Clinical cases}

Case 1

Patient K., an 18-year-old male, presented to the clinic with a lesion localized to the left nasal sidewall (Fig. 2). History: the lesion had been there since birth. As the patient got into puberty, he noticed that the lesion started to grow slowly and exuded a small amount of yellowish material when squeezed. The patient attempted to squeeze out the lesion on numerous 
occasions. A year before he presented to the clinic, the lesion had developed a horn in the center growing up to $0.5 \mathrm{~cm}$ in the past 6 months (Fig. 3). Status localis: the skin complexion was normal; the T- zone produced excessive oil; closed comedones were present. There was an oval elongated light- pink plaque of $0.5 \times 0.8 \mathrm{~cm}$ in size on the left nasal sidewall; the plaque formed by papules had a lobular structure and was slightly raised above the skin surface. In the center of the plaque there was a $0.5 \mathrm{~cm}$ tall cylinder-shaped horn of $0.1 \times 0.1 \mathrm{~cm}$ in size at its base. The tip of the horn appeared as a thick layered corneous mass. The lesion was soft and painless on palpation. Histological analysis revealed papillomatous hyperplasia of the epidermis and sebaceous glands. Clinical diagnosis: D23.3, nevus sebaceus of Jadassohn, cutaneous horn. Considering the localization and the small size of the lesion, a decision was made to remove it under local anesthesia using the $\mathrm{CO}_{2}$ laser. A follow-up examination 2 weeks after the procedure revealed formation of a post-operative normotrophic scar (Fig. 4)

Case 2

Patient A., a 30-year-old female, presented to the clinic with a skin lesion on the forehead for aesthetic correction (Fig. 5). History: the lesion was present at birth. As the patient went into puberty, the lesion slightly increased in size, rose more above the skin surface and grew darker. According to the patient, there were no changes to the lesion in the past 10 years. Status localis: the skin complexion was normal. There were papules forming an oval elongated light-brown plaque of $1.7 \times 1.1 \mathrm{~cm}$ in size; the surface of the plaque was nodular. The lesion had a lobular structure and was slightly raised above the skin surface. It was soft and painless to the touch. Histological analysis revealed the subepithelial overgrowth of sebaceous glands (Fig. 6). Clinical diagnosis: D23.3, nevus sebaceus of Jadassohn. The lesion was removed under local anesthesia using the $\mathrm{CO}_{2}$ laser. The follow-up examination conducted 2 weeks after the procedure revealed formation of a post-operative normotrophic scar (Fig. 7).

\section{Discussion}

There is no consensus on whether it is wise to remove NSJ or when to do it. Until puberty the lesion is usually very inconspicuous. After puberty NSJ evolves into a secondary benign neoplasm in $10 \%$ to $30 \%$ of cases [5]. The literature describes cases of benign tumors growing inside NSJ, of which trichoblastoma and syringocystadenoma are the most common [6]. Such transformation of NSJ causes additional psychological discomfort to the patient and requires aesthetic correction. Patients with NSJ rarely develop a cutaneous horn in the lesion $[7,8]$. There are no accurate figures on the frequency of malignant NSJ transformations. Both Russian [2] and foreign [9] researchers believe NSJ rarely becomes malignant. Other researchers estimate that malignancies develop in $22 \%$ of cases [10], the majority of which are patients over 50 years of age $[11,12]$. It has been proved that the risk of malignant transformation increases with age [11]. The literature reports a few cases of multiple neoplasms within the same NSJ in patients over 50 [13]. The typical NSJ localization (the face and scalp) contributes to the risk of malignant transformation. At the cellular level, NSJ consists of pluripotent epidermal stem cells, which create a nurturing environment for a malignancy $[2,4]$. Because there is a risk of malignant transformation and the presence of NSJ causes patients psychological discomfort, we believe it justifiable to remove the lesion after puberty. There

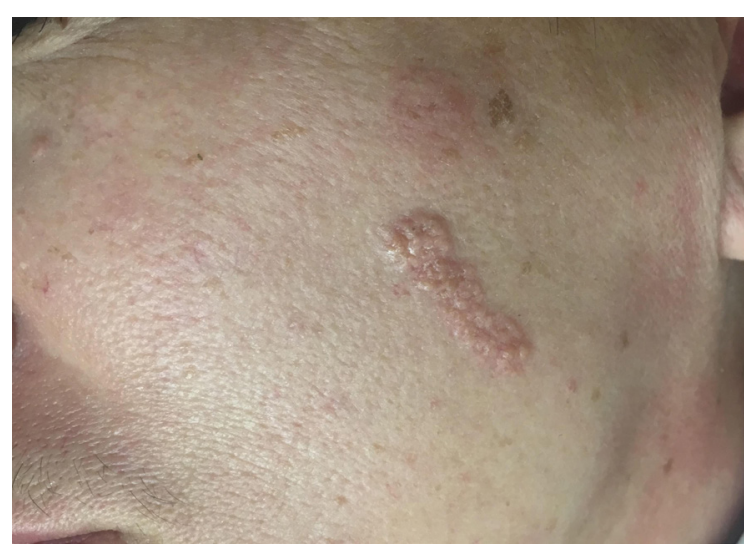

Fig. 1. Nevus sebaceus of Jadassohn in a 35-year-old female

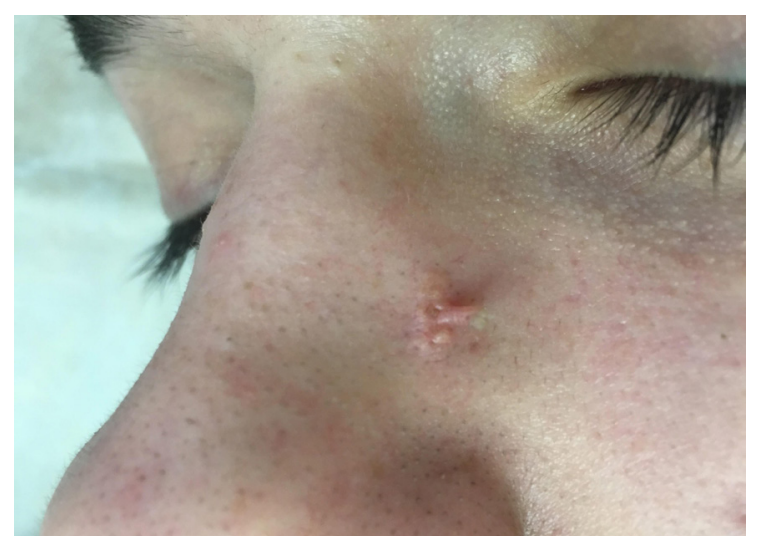

Fig. 2. Patient K., 18 years old. Nevus sebaceus of Jadassohn with a cutaneous horn on the left nasal sidewall (side view)

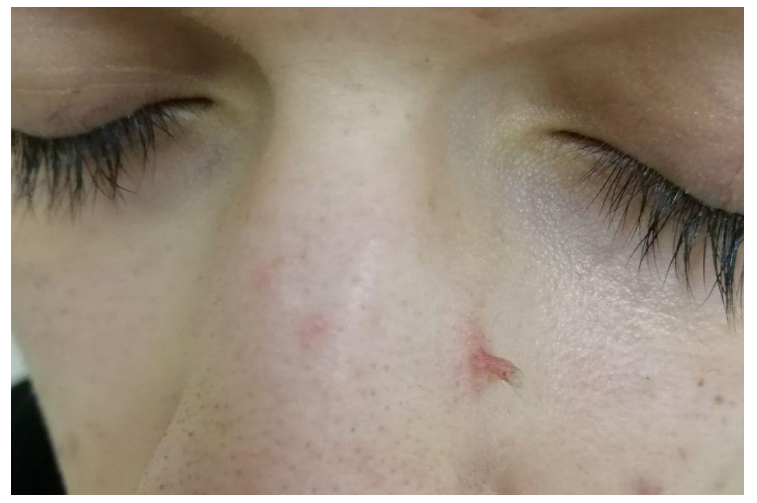

Fig. 3. The same patient. Nevus sebaceus of Jadassohn with a cutaneous horn on the left nasal sidewall (front view)

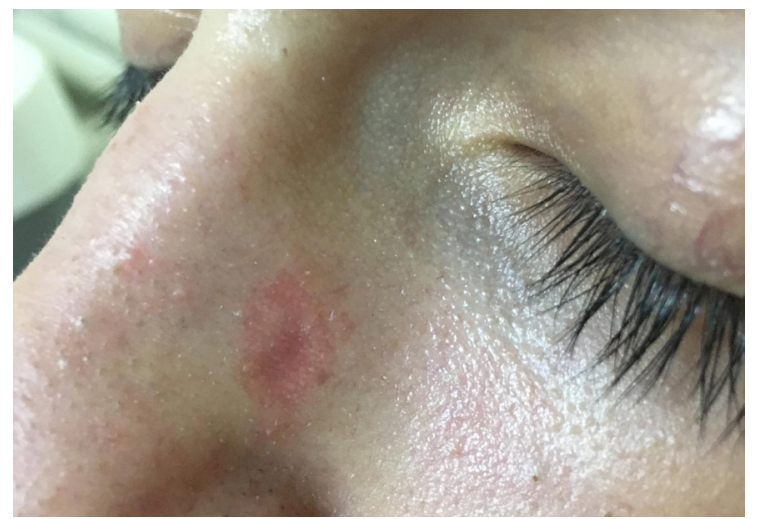

Fig. 4. The same patient. Formation of a post-operative normotrophic scar following the $\mathrm{CO}_{2}$ laser treatment 


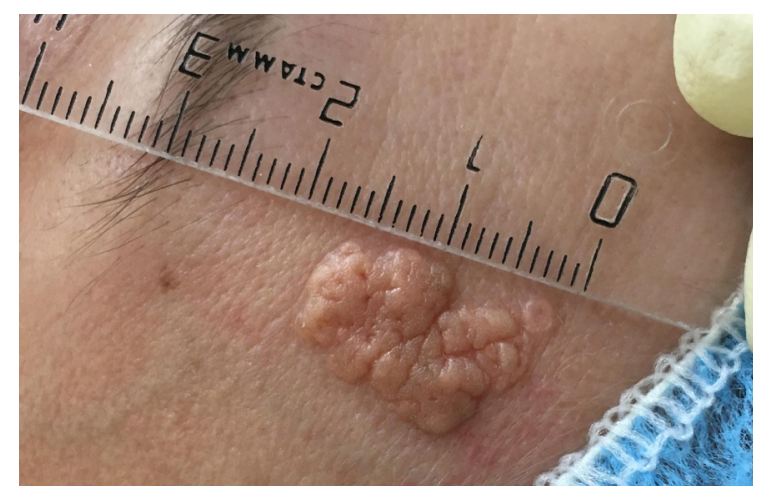

Fig. 5. Patient A., 30 years old. Nevus sebaceus of Jadassohn on the forehead

are a lot of treatment options including curettage, cautery, cryotherapy, photodynamic therapy, laser ablation, and surgical excision. The $\mathrm{CO}_{2}$ laser has been successfully used in children [14]. This method is characterized by high efficacy and efficiency, little damage to healthy tissues and good cosmetic results. In patients over 50 surgical excision should be preferred. If surgery is impossible, long-term observation is indicated.

\section{CONCLUSIONS}

The described clinical cases demonstrate a good cosmetic effect of the $\mathrm{CO}_{2}$-laser used to treat nevus sebaceus of Jadassohn. We recommend opting for this method in young patients with small lesions of no bigger than $2-3 \mathrm{~cm}$ in size.

\section{References}

1. Lantis S, Leyden J, Heaton C. Nevus sebaceous Jadassohn. Arch Dermatol 1968, 98: 117-23.

2. Molochkov VA, Mardi Sh. K razvitiju bazaliomy na fone nevusa sal'nyh zheljoz Jadassona. Al'manah klinicheskoj mediciny. 2007; 15: 232-5.

3. Simi C, Rajalakshmi T, Correa M. Clinicopathologic analysis of 21 cases of nevus sebaceus: A retrospective study. Indian J Dermatol Venereol Leprol. 2008; 74 (6): 625-7.

4. Alessi E, Sala F. Nevus sebaceus. A clinicopathologic study of its evolution. Am J Dermatopathol. 1986; 8 (1): 27-31.

5. Liu Y, Valdebran M, Chen J, Elbendary A, Wu F, Xu M. Nevus sebaceous of Jadassohn with eight secondary tumors of follicular sebaceous, and sweat gland differentiation. Am J Dermatopathol. 2016; 38 (11): 861-6.

6. Jaqueti G, Requena L, Sánchez Yus E. Trichoblastoma is the most common neoplasm developed in nevus sebaceus of Jadassohn. A clinicopathologic study of a series of 155 cases. Am J Dermatopathol. 2000; 22 (2): 108-18.

7. Pointdujour-Lim R, Marous MR, Satija CE, Douglass AM, Eagle RC, Shields CL. Cutaneous Horn of the Eyelid in 13 Cases. Ophthalmic Plastic and Reconstructive Surgery. 2017; 33 (4): 233-6.

8. Arvas L, Livaoglu M, Karacal N, Sozen E, Kara B. Giant cutaneous

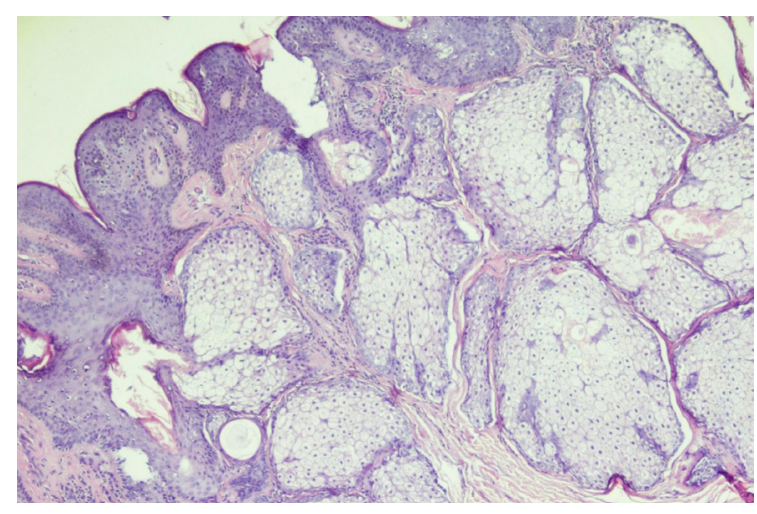

Fig. 6. The histological slide of skin with the subepithelial proliferation of sebaceous glands. Staining: hematoxylin-eosin; magnification $\times 40$

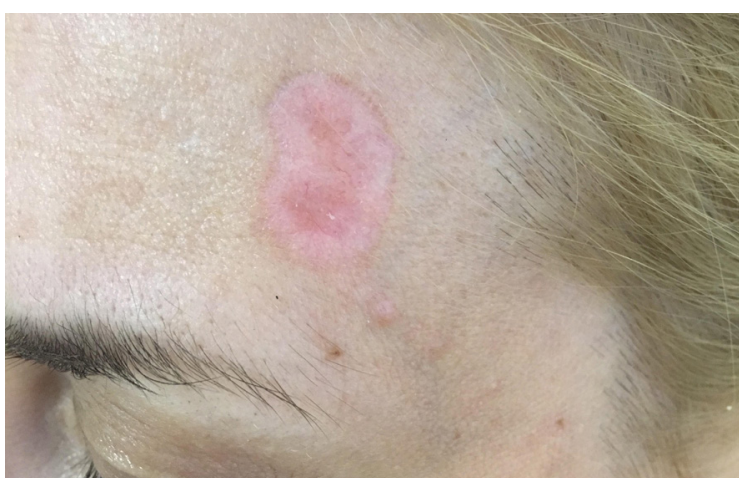

Fig. 7. Patient A., 30 years old. Formation of a post-operative normotrophic scar following the $\mathrm{CO}_{2}$ laser treatment horn with naevus sebaceous. J Plast Reconstr Aesthet Surg. 2007; 60 (11): 1268-9.

9. Kamyab-Hesari K, Seirafi H, Jahan S, Aghzadeh N, Hejazi P, Azizpour A, et al. Nevus sebaceus: A clinicopathological study of 168 cases and review of the literature. Int J Dermatol. 2016; 55 (2): 193-200.

10. Westfried M, Mikhail GR. Multifocal Basal-Cell Carcinomas in a Nevus Sebaceus of Jadassohn. J Dermatol Surg Oncol. 1981; 7 (5): 420-2.

11. Idriss $\mathrm{MH}$, Elston DM. Secondary neoplasms associated with nevus sebaceus of Jadassohn: A study of 707 cases. J Am Academ Dermatol. 2014; 70 (2): 332-7.

12. Jardim MML, Souza BC, Fraga RC. Rare desmoplastic trichilemmoma associated with sebaceous nevus. Anais Brasileiros de Dermatogia. 2017; 92 (6): 836-7.

13. Liu Y, Valdebran M, Chen J, Elberdary A, Wu F, Xu M. Nevus Sebaceous of Jadassohn wiht Eight Secondary Tumors of Follicular, Sebaceous, and Sweat Gland Differentiation. Am J Dermatopathol. 2016; 38 (11): 861-6.

14. Ashinoff R. Linear Nevus Sebaceus of Jadassohn Treated with the Carbon Dioxide Laser. Pediatr Dermatol. 1993; 10 (2):189-91.

\section{Литература}

1. Lantis S, Leyden J, Heaton C. Nevus sebaceous Jadassohn. Arch Dermatol 1968, 98: 117-23.

2. Молочков В. А., Марди Ш. К развитию базалиомы на фоне невуса сальных желёз Ядассона. Альманах клинической

медицины. 2007; 15: 232-5.

3. Simi C, Rajalakshmi T, Correa M. Clinicopathologic analysis of 21 cases of nevus sebaceus: A retrospective study. Indian J Dermatol Venereol Leprol. 2008; 74 (6): 625-7. 


\section{КЛИНИЧЕСКИЙ СЛУЧАЙ І ДЕРМАТОЛОГИЯ}

4. Alessi E, Sala F. Nevus sebaceus. A clinicopathologic study of its evolution. Am J Dermatopathol. 1986; 8 (1): 27-31.

5. Liu Y, Valdebran M, Chen J, Elbendary A, Wu F, Xu M. Nevus sebaceous of Jadassohn with eight secondary tumors of follicular, sebaceous, and sweat gland differentiation. Am J Dermatopathol. 2016; 38 (11): 861-6.

6. Jaqueti G, Requena L, Sánchez Yus E. Trichoblastoma is the most common neoplasm developed in nevus sebaceus of Jadassohn. A clinicopathologic study of a series of 155 cases. Am J Dermatopathol. 2000; 22 (2): 108-18.

7. Pointdujour-Lim R, Marous MR, Satija CE, Douglass AM, Eagle RC, Shields CL. Cutaneous Horn of the Eyelid in 13 Cases. Ophthalmic Plastic and Reconstructive Surgery. 2017; 33 (4): 233-6.

8. Arvas L, Livaoglu M, Karacal N, Sozen E, Kara B. Giant cutaneous horn with naevus sebaceous. J Plast Reconstr Aesthet Surg. 2007; 60 (11): 1268-9.

9. Kamyab-Hesari K, Seirafi H, Jahan S, Aghzadeh N, Hejazi P, Azizpour A, et al. Nevus sebaceus: A clinicopathological study of
168 cases and review of the literature. Int J Dermatol. 2016; 55 (2): 193-200.

10. Westfried M, Mikhail GR. Multifocal Basal-Cell Carcinomas in a Nevus Sebaceus of Jadassohn. J Dermatol Surg Oncol. 1981; 7 (5): 420-2.

11. Idriss $\mathrm{MH}$, Elston DM. Secondary neoplasms associated with nevus sebaceus of Jadassohn: A study of 707 cases. J Am Academ Dermatol. 2014; 70 (2): 332-7.

12. Jardim MML, Souza BC, Fraga RC. Rare desmoplastic trichilemmoma associated with sebaceous nevus. Anais Brasileiros de Dermatogia. 2017; 92 (6): 836-7.

13. Liu $Y$, Valdebran M, Chen J, Elberdary A, Wu F, Xu M. Nevus Sebaceous of Jadassohn wiht Eight Secondary Tumors of Follicular, Sebaceous, and Sweat Gland Differentiation. Am J Dermatopathol. 2016; 38 (11): 861-6.

14. Ashinoff R. Linear Nevus Sebaceus of Jadassohn Treated with the Carbon Dioxide Laser. Pediatr Dermatol. 1993; 10 (2):189-91. 